\title{
The Dynamic Holistic Development of Human Potentials and Wellbeing: Implication on Educational Policies
}

\author{
Rosadah Abd Majid ${ }^{\mathrm{a}}$, Manisah Mohd Ali ${ }^{\mathrm{b}}$, Norshidah Mohd Salleh ${ }^{\mathrm{c}}$, Aliza Alias ${ }^{\mathrm{d}}$, \\ Ramesh Kanapathy ${ }^{e}$, Khadijah Said Hashim ${ }^{\mathrm{f}}$ \\ a, b, c, d Faculty of Education, UKM, Malaysia \\ ${ }^{\mathrm{e}}$ Kementerian Pendidikan Malaysia, Malaysia \\ ${ }^{\mathrm{f}}$ Faculty of Education UiTM, Malaysia \\ Email: rosadah@ukm.edu.my
}

\begin{abstract}
Education plays an important role in its mission to develop every individual student to become the best person whose potential has been developed to optimal level. This paper discusses a framework of individual's holistic potential development. Holistic education includes processes and efforts to realize the progress of individual potentials from all dimensions which include; physical, social, intellect, emotion, aesthetic, creativity, and spirituality or as referred by Malaysian Educational Philosophy as physical, emotion, spiritual, and intellect. Holistic developmental process is regarded as the aim and effort to develop individuals to be mindful and skillful to benefit self and the society at large. Development of social responsibility is the outermost circle of the conceptual framework. It signifies the individual's awareness of his purpose in life, for continuous wellbeing and happiness when he benefits other people from his potential development. Individual potential development starts from the innermost circle describing his self-development, developing wellbeing, to feel peace and calm, and worthiness. Innermost circle refers to the individual state of happiness or wellbeing when his spiritual dimension is fulfilled and developed. The middle or second circle of the framework refers to the developmental process of character and excellence for individual's optimal potential development through adults caring and teachers' application of 'love pedagogy'. Among the catalysts for the developmental process are: conducive environment, emotional strength and self-actualization, chance factor, time investment, effort, and financial resource. Individual development at the micro level during childhood age will become elements for the developmental process during adolescents and adulthood. Implications of the framework of individual's holistic potential development on educational policies will be discussed in this paper.
\end{abstract}

Keywords: wellbeing, holistic development, potential development, love pedagogy.

Education is the core of the development and wellbeing of an individual and his country. Various contemporary issues involving juvenile crime lead us to be doubtful on the effectiveness of the education system. Therefore, the educational system needs reorientation and new insights to generate wellbeing in the society. Holistic education is an educational philosophy that is not limited to the development of academic skills such as writing, reading, and counting. Holistic education is based on the premise that every individual will find his/ her own identity, meaning and life objectives through communication and interaction with community, environment, and human values such as love and peace (Mayes, Maile-Cutri, Goslin, \& Montero, 2016). Therefore, holistic education also includes and emphasizes on the developmental aspects of individual relationship, responsibility and respecting other individuals or environment. Educational objectives should not be limited to academic achievement. It also needs to work on the achievement of society's wellbeing or happiness. Wellbeing is subjective and it depends on the thinking and on the emotional state of an individual. People who experience subjective wellbeing are more prepared to face challenges, solve problems with creativity, and capable of creating harmony in any situation. Subjective wellbeing is also influenced by individual's personality and their problems solving activities. Resilient individual has the ability to withstand risk, pressure and trauma while successfully dealing and adapting with challenging situation (Glantz \& Johnson, 1999).

There is a need to discuss on how the education system evaluate every individual student from the aspect of their potential and how should the effort and approaches develop those potentials. This paperwork discusses the dynamic of the effort to develop the students internally from within the person, and externally involving the students' interactions with his/ her surroundings. These include emotional interactions and its dynamicity, spiritual development, pro-social behaviour, and altruism. Teachers play significant roles in assisting the interpretation of events while giving 
cognitive and emotional supports so that the dynamic of the problems or challenges can be understood, accepted and handled in the best possible manner. These kinds of interactions need good and positive relationship between teachers and their students, and this is regarded as the essence of love pedagogy (Stehlik, 2016). Needless to mention that love pedagogy should be applied during the educational process that is during conducting lessons inside and outside classrooms. This educational approach requires teachers to have space and opportunities to deal with students in class to ensure their wellbeing. Similar to the educational system in Finland is where students' wellbeing is the main priority (Stehlik, 2016). This pedagogical approach prioritizes good and harmonious relationship between teachers and students. It starts from the affection of teachers to students and prioritizing students' wellbeing. Students' wellbeing and happiness is important to ensure their continuously potential development for the benefit of themselves and others. Thus, love pedagogy does not mean teachers' gentle approaches and lowering achievement standards. Instead, it emphasizes on recognizing excellent achievements. Students are nurtured to develop determinations in achieving excellence in the domains of their potentials and talents for the wellbeing and prosperity of self, institution and society. Pedagogy itself is an art and science of education in realizing the goodwill of the educational purpose, to design and develop "success for all" (Määttä \& Uusiautti, 2011).

\section{DISCUSSION}

\section{Subjective Wellbeing}

Individual happiness is the results of combination from several satisfying events in one's life (Diener 1984). Subjective wellbeing is one's perception towards his own life experiences. It is from the contributions of positive experiences in an individual's life. In other words, positive experiences in an individual life contributes to happiness and life satisfaction of that individual. Changes in situations or environments will affect life experiences and individual's wellbeing. For example, changes in classroom, or home environment, or support system will affect life experiences and will bring changes to an individual subjective wellbeing (Wong, 2012)

Wellbeing is a subjective concept that brings different meaning to different persons (Wan, Maarof, \& Zahid, 2009). According to researchers in wellbeing, happiness is regarded as the most valuable achievement in one's life. According Diener (2000), happiness is associated with wellbeing, and usually a happy person is healthy, less stressful, and effective. Happiness is the process not the target. It can be concluded that wellbeing depends on how far a person can free himself from problems that appear in his life, while gaining perfection, prosperity, benefit and satisfaction in fulfilling his own needs until he is able to benefits other people.

Subjective wellbeing is determined by the person himself based on how he/she interprets the events experienced in his/her life. It depends on the person's personality and attitude. Changes in perception, confidence, aspirations and personality types may effect a person's subjective wellbeing (Jati, 2010). Subjective wellbeing is influenced by cognitive and affective evaluation (Diener, 2000). When a person is structuring and evaluating an experience from past events, it is known as cognitive process. While, evaluation of an event affected by mood which could be influenced by culture, environments and situations is known as affective process. Other than that, cognitive evaluation can be defined as evaluation on the overall life satisfaction, or evaluation on just certain aspects such as life satisfaction, interests, and relationships. On the other hand, affective evaluation looks at pleasant or unpleasant emotional reactions towards life events. Subjective wellbeing or happiness also depends on individual's resilience or ability to face challenges in life.

\section{Resilience}

The term resilience was used in three different phenomenons: (1) Individual who experienced traumatic events in life but had perfectly recovered (2) Individual from high risk group but managed to achieve better than expected, and (3) Individual who showed positive adaptations although living a stressful live (Masten, Best \& Garmezy, 1990). Resilience is also defined as the ability to rise up again, to cope and adapt while developing self-competency in the face of adversity (Gordon, 1995). When a person is facing stressful situation, ideally his inner self-control will function as buffer to the pressure (Henderson \& Milstein, 2003). This buffer control assists the person to cope positively towards stress and emotional disturbances. Besides, buffer control can help integrating the continuous emotional disturbances and stress to form new sets of behaviour which shows improvement or changes in the person's level of resilience (Henderson \& Milstein, 2003). Generally, resilience is determined by the individual's surroundings. Positive surroundings lead to positive resilience and vice versa, if the surroundings are negative then it leads to stress (Rutter, 1985). It is the wisdom of the educator to play significant roles in providing and maintaining the positive environment. The teacher or educator need to be a person who cares and always want the best for their students out our sincere concern and affection. 


\section{Figure 1. Dynamic Holistic Individual Potential Development}

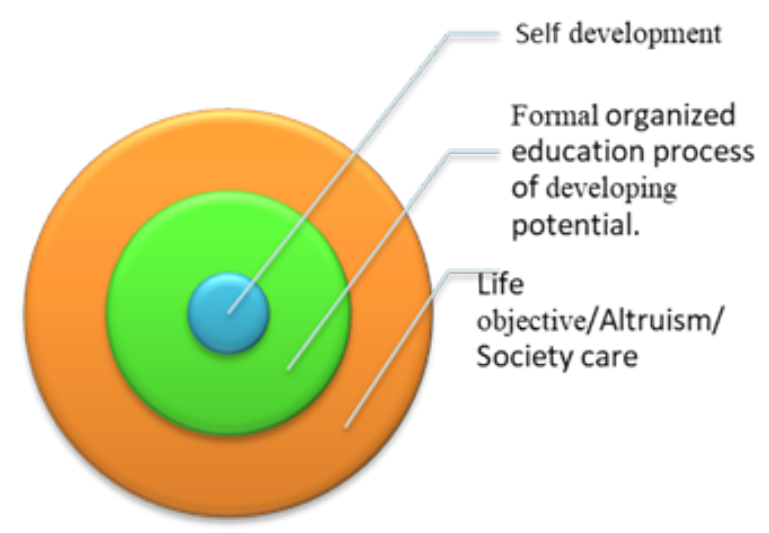

Therefore, it is again proven on the importance of love pedagogy to maintain emotional stability of students in various situations and circumstances.

\section{Positive Psychoogy}

Positive psychology was introduced by Abraham Maslow in 1954. This is a well-known theory which among others introducing hierarchy of needs model, motivation and needs theory, concepts of selfactualization and peak experiences. This theory and model emphasize on psychological needs focussing on human potentials rather than on human weakness (Bridges \& Wertz, 2009). Positive psychology focuses on wellbeing, happiness, prosperity, selfstrength, wisdom, creativity, imagination and positive characteristics of an individual, groups or organizations. Prosperity or wellbeing is referred to when a person is healthy mentally and possesses positive emotions and positive thinking at all time (Michalec, Keyes, \& Nalkur, 2009).

According to Hefferson and Boniwell (2011), positive psychology concentrates on positive experiences at three different times; in the past, at present, and in the future. In the past it affects the person's wellbeing and satisfaction. At present, it is about happiness. In the future positive psychology is about hope and confidence. This positive psychology is divided into three nods: (1) subjective nod positive experiences from three different times such as wellbeing, confidence, hope, happiness and satisfaction, (2) individual nod focusing on a good person features such as bravery, endurance, wisdom, talent, affection and creativity, (3) group nod - positive institution, positive organization, citizen and society. Within the scientific community, positive psychology is a new perspective investigating on human prosperity, wellbeing and happiness. Research about happiness can be traced to as early as during the Greek era. Figures such as Aristotle, Socrates and Plato believed that a person with good morality would gain true happiness while the Epicurus and Utilitarian group found that happiness was overflow of positive feelings and life enjoyment (Hefferson \& Boniwell, 2011).

Subjective wellbeing is used as a measurement to evaluate levels of wellbeing or the quality of life of an individual (Keyes, Shmotkin \& Ryff, 2002). Definition of the quality of life according to the Malaysia Quality of Life 1999 report, is healthy lifestyle, selfimprovement, freedom in acquiring knowledge and acquiring economic status that exceeds the individual's basic needs, as well as fulfilling psychological needs to reach level of social wellbeing inline with the national aspiration (Economy Planning Unit, 1999). There are two types of indicators to determine quality of life; subjective indicator and objective indicator. Objective indicator refers to environment such as financial, facilities and housing. Subjective indicator will explain a person's evaluation or view about his or her life.

\section{Developing Individual Potential}

Human being is born with diverse potentials. Potential is human ability or talent that need to be nurtured to benefit mankind. Regardless whether the students are considered to have special needs or typical, everyone is blessed with different abilities. Therefore, educators, teachers and parents need to identify and celebrate these diverse potentials among our children. Developing human potential is important because collectively it will contribute towards the development of the nation and human civilization. Educational institutions conducting formal or informal educational processes, has the mission to develop and nurture the potential of all students. The dynamicity of the educational process and practice involve three stages of human development represented by three main parts (Figure 1). The first stage, the inner most circle representing self-development, followed by the second stage representing formally organized educational programs, and complemented by the third stage representing the process of developing meaning to purpose in life, to serve and be of benefit to mankind and to the environment. All this process is dynamic and can occur simultaneously. Teachers, educators and parents play important roles in providing continuous guidance and supports for the students or children to assist them to reach equilibrium in handling the dynamicity of self-potential development.

Figure 1, illustrates the proposed dynamic framework that represents the process of developing excellent individual based on holistic educational philosophy. It starts with the innermost circle that represents the heart of the individual potential developmental process. It represents self-development. A person whose self is in the state of peace or 'subjective 
wellbeing' will be better able to accommodate with the potential development program planned for him or her. Students who achieve subjective wellbeing are at peace with him/herself. They are 'happy' and will be at ease to learn and to be taught. Thus, it has to be in the educational policy that teachers need to have the knowledge and skills on how to assist and guide students to achieve subjective wellbeing. It relies on teachers' effective communication skills, their inter and intrapersonal skills, as well as listening skills. Beginning with teachers' having sincere affections towards their students, and showing sincere caring attitudes for them. Love pedagogy becomes the essence of teacher student's interactions. It should be made a policy that teacher training need to include topics such as; understanding of self and others, building and maintaining positive self-concept, understanding what influence individual's behaviour and attitudes, and interacting positively with others. The teachers themselves need to acquire these skills as prerequisite competency for educators. It is very important that in pre-service as well as for in-service teacher training to include those elements mentioned in the courses. Discussions, reflections, and interactive lessons and activities are some of the approaches suggested by Darling-Hammond, Hyler, and Gardner (2017). These kinds of activities are important for adults' learners to utilize past experiences as their resources, making learning effective and meaningful.

The middle circle illustrates the dynamic process of potential development that usually occurs in formal setting. Gagne (2003) describes the process through Differentiated Model of Gifted and Talented, DMGT. Efforts to develop potential and talent is considered as investment. It includes time, energy and financial investment. A person's intrapersonal skills and his/ her conducive environment for potential development process is considered as catalysts to the process. While developing students' potential, it is necessary for educators to instil the purpose in their students' life. Working hard to realize one's potential need to be made meaningful by relating it to purpose in life. Thus, this aspect of relating own's commitments to purpose in life has to be explicitly discussed with students. Teaching and learning policy has to embrace this particular approach, that is in to discuss and relate students' purpose in life with their educational activities. Allow students to identify their purpose in life, and discuss on how to ensure that they will achieve those purpose via their educational endeavour.

The third outermost circle represents the process of bringing meaning of the potential development in fulfilling human's social responsibility. This in essence regards the nature of potential development as prosocial and altruistic in nature. The outcome of human potential development is to be beneficial to mankind. Although at times these may involve efforts which are of high risks. An altruistic individual will be willing to work hard even if they face the possibilities of loss. However, believing in their mission to benefit others, they are determined to proceed. The education policy need to specify that students have to fulfil a certain amount of time to be in charged or doing service to others voluntarily. Volunteering service could be delivered to specific institutions such as orphanages, old folks' homes, schools, hospitals, and the like. Besides, volunteerism could also be dedicated to specific individuals who are in needs of supports and guidance. The educational policy need to make service learning and volunteerism as necessary components in complementing the academic curriculum.

Developmental processes in all the three stages or levels are dynamic in nature due to the interactions of elements within individuals themselves or with other environmental elements. In all the stages of holistic individual potential development discussed in this paper, it emphasizes that; support, guidance, and encouragement from teachers, educators and parents, are necessary and very important. The seed of all these positive interactions is teacher's affection and care of their students. This practice and elements of education need to be implemented and nurtured in the system, and this teaching and learning approach is known as "love pedagogy". Love pedagogy refers to good and healthy relationship which is based on trust, between students, teachers, parents and administrators. Finland educational system whose excellence has been much talked about, sets love pedagogy as the trust or foundation in the educational process. All processes involved are dynamic in nature when teachers and educators play important and significant roles to provide continuous guidance to the students to develop their potentials, and build their resilience to achieve subjective wellbeing. Subjective wellbeing is necessary and a prerequisite in developing students' potentials and excellence.

\section{Implication on Educational Policy}

Educational policy is necessary to ensure quality education. Educational policies lay down specific doable terms and conditions to be fulfilled in the education sectors. Teachers play significant roles to develop students' potentials holistically. Thus, teachers need good and clear guidelines on how to become the teachers who will be able to design and conduct lessons effectively. They also need to ensure a conducive and therapeutic environment to nurture students' inner strengths and holistic development. This is inline with key attributes aspired for Malaysian students (Malaysia Education Blueprint 2013-2025). Therefore, besides focussing on the teachers, the policy also need to 
focus on the content of the curriculum, the curriculum design, and curriculum delivery. These are some of the suggestions and recommendations to supplement the education system in developing students' potential holistically.

\section{Teacher Selection and Teacher Training Policy}

Select the most capable candidates with the most suitable attitudes. Special aptitude tests and interviews need to be conducted prior to selecting candidates for teacher training. Only those candidates who pass both the aptitude test and the interview will be offered teacher training course.

Teachers candidates need to have good understanding on students' unique needs. Thus, teacher training curriculum needs to include topics on students' diverse characteristics and their diverse learning needs. This is very important because this is in fact the foundation or the seed for love pedagogy to be materialized in the education system.

Preservice training as well as the in-service training will have to equipped and to recharge teachers with knowledge and skills on how to develop selfsubjective wellbeing for him/herself, and also to train them to assist students in developing their subjective wellbeing.

\section{Teaching and facilitating policy}

Teachers have to ensure safe, friendly and inclusive environment. Students will feel at ease and not threatened by the environment and will be able to unleash their potentials. Teachers will have to adhere to the principles of love pedagogy in ensuring this kind of environment and appropriate educational approaches for the students.

Teachers' roles are to facilitate, to coach, and to advocate for their students. Teaching is not just transferring of knowledge, instead teachers' roles are to mobilize and to motivate students to be actively engaged in their learning, and to bring meaning to what was learnt.

\section{Teachers' support policy}

Educational institutions need to employ periodic monitoring and support for all educators and teachers. Like students, teachers are diverse and have diverse needs as well. They need guidance and support to maintain energetic and resourceful in the teaching profession. Thus, educational institutions need to provide therapeutic environment so that teachers could recharge and reenergize to be better able to continue with their professional endeavour in education.
Educational institutions need to create support groups and discussion groups for the educators. This will be platforms for teachers and educators to share their insights and reflections, and to get feedbacks in improving their actions.

\section{Curriculum design and curriculum delivery policy}

Curriculum content or syllabus need to be flexible in nature, catering for student of diverse abilities and interests. This is important to ensure success in developing potentials of all students. Students with high intellectual ability need to learn topics in depth and be enriched academically. This is their educational needs. On the other hand, students who are intellectually challenged need an adjusted curriculum to meet their learning needs. Teachers should be given the liberty of designing curriculum to suit learners' needs. They need to be equipped with knowledge and skills on curriculum design, adjustments and adaptations.

Teachers will need to align curriculum delivery to promote students' self-development, such as to bring meanings from the topic learnt. Curriculum delivery need to be interactive to embed good values and understanding others. Teachers have to ensure safe and supportive environment during lessons so that positive and fruitful interactions between teachers and students, and between students and students will take place. This will provide platforms for teachers to guide students to enhance their inner strengths and achieve subjective wellbeing.

\section{CONCLUSION AND SUGGESTION}

Every child's potential is a gift that need to be nurtured and developed optimally for his/her own wellbeing and for the benefit of mankind. The education system plays significant roles in human potential development. Regardless of the uniqueness of the person, whether considered typical or with special needs, educators still need to identify potential or strength in every student. They need to provide guidance, supports and encouragements to students, to develop those potentials. They have the responsibility of nurturing students to be developed optimally. It is also important that they ensure suitable and conducive environment to facilitate in educating students holistically and effectively. It begins with consciously educating students to develop and sustain inner peace or self-tranquillity. These require educators with caring and affectionate personality, to adhere to "love pedagogy" as the foundation in educating their students. Consecutively, the education system needs to encourage and provide opportunities for students to serve others directly or indirectly. Indeed, the ultimate and the most important goal of education is to develop and to maintain individual and societal wellbeing. 


\section{Apreciation}

We would like to express our appreciation to the Ministry of Education Malaysia for awarding scholarship to Ramesh Kanapathy to pursue his Doctoral Degree at Universiti Kebangsaan Malaysia. Some parts of his work was referred in this paper.

\section{REFERENCES}

Bridges, S. K., \& Wertz, F. J. (2009). Maslow, Abraham. In S.J. Lopez (Ed.), The Encyclopedia of Positive Psychology (pp. 599-600). West Sussex, United Kingdom: John Wiley \& Sons Ltd.

Darling-Hammond, L., Hyler, M. E., \& Gardner, M. (2017). Effective teacher professional development. Carlifornia: Learning Policy Institute

Diener, Ed. (1984). Subjective well-being. Psychological Bulletin, 95(3), 542-575.

Diener, Ed. (2000). Subjective well-being: The science of happiness and a proposal for a national index. American Psychologist, 55(1), 34-43.

Gagne, F. (2003). Transforming Gifts into Talents: The DMGT as a Developmental Theory. In N. Colangelo \& G. A. Davis (Eds.), Handbook of gifted education ( $3^{\text {rd }}$ ed.), pp. 60-74. Boston: Allyn and Bacon.

Glantz, M. D., \& Johnson, J. L. (1999). Resiliency and development: Positive life adaptations. New York: Kluwer Academic.

Gordon, K.A. (1995). The self-concept and motivational patterns of resilient African American high school students. Journal of Black Psychology, 21, 239255

Hefferson, K. \& Boniwell, I. (2011). Positive Psychology Theory, Research and Applications. Berkshire England: McGraw-Hill Education

Henderson, N., \& Milstein, M. (2003). Resiliency in schools: Making it happen for students and educators. Thousand Oaks, CA: Corwin Press, INC.

Jati, A. (2010). Subjective well-being (kesejahteraan subjektif) dan kepuasan kerja pada staf pengajar (dosen) di lingkungan fakultas psikologi Universitas Diponegoro. Jurnal Psikologi Undip, 8(2), 117-123
Keyes, C. L. M., Shmotkin, D., \& Ryff, C. D. 2002. Optimizing well-being: The empiri- cal encounter of two traditions. Journal of Personality and Social Psychology, 82, 1007-1022

Määttä, K. \& Uusiautti, S.(2011). Pedagogical Love and Good Teacherhood. In Education, 17(2), 2941.

Malaysia Education Blueprint (2013-2025). Putrajaya: Ministry of Education Malaysia.

Masten, A., Best, K., \& Garmezy, N. (1990). Resilience and development: Contributions from the study of children who overcome adversity. Development and Psychopathology, 2, 425-444.

Mayes, C., Maile-Cutri, R., Goslin, N., \&. Montero, F. (2016). Understanding the Whole Student: Holistic Multicultural Education. Maryland: Rowman and Littlefield.

Michalec, B., Keyes, C., \& Nalkur, S. (2009). Flourishing. In S. Lopez (ed.) The Encyclopedia of Positive Psychology(pp. 391-4). Chichester: Blackwell Publishing Ltd

Rutter, M. (1985). Resilience in the Face of Adversity: Protective Factors and Resistance to Psychiatric Disorder. British Journal of Psychiatry, 147, 598611

Stehlik, T. (2016). Is "pedagogical love" the secret success to Finland's Educational sucsess? Australian Associatian for Research in Education. https://www.aare.edu.au/blog/?p=1578.

Unit Perancang Ekonomi (1999). Laporan Kualiti Hidup Malaysia 1999. Jabatan Perdana Menteri. Dicapai pada Oktober 1, 2010 dari http://202.75.7.57/ New\% 20 Folder/ publication /mqli99/All.pdf

Wan, I. W. A., Ma'rof, R., Zahid, E. A. H. H. (2009). Kesejahteraan subjektif warga tua di malaysia: kes warga tua desa kelantan. International Journal of Management Studies (IJMS), 16(2), 63-96.

Wong, Y. H. P. (2012). Subjective well-being among Hong Kong kindergarten teachers: the roles of perceived work environment, personality types, and resilience. Thesis PHD. The University of Hong Kong. 